\title{
顔面㾏攣症例の神経耳科学的検討
}

\author{
兵行彦・犬塚一男・稲福繁 \\ 石神 寛通・瀧本 勲・杉山貴志子*
}

\section{Neurootological Investigations in Patients with Hemifacial Spasm}

\author{
Yukihiko Hyo, Ichio Inuzuka, Shigeru Inafuku, \\ Hiromichi Ishigami and Isao Takimoto \\ (Aichi Medical University) \\ Kishiko Sugiyama \\ (Nagoya City)
}

\begin{abstract}
Preoperative neurootological investigation were conducted in 21 patients treated for hemifacial spasm (HFS) by microvascular decompression. There were no significant findings from these investigations. We supposed that the neurovascular compression which caused HFS did not affect the eighth cranial nerve.
\end{abstract}

Key words: neurootological investigations, hemifacial spasm, neurovascular compression

\section{はじめに}

一側性顔面痤卛 (hemifacial spasm, 以下 HFS) は片側の顔面に不随意に痤攣を来す疾患 で, その原因は椎骨動脈, 前下小脳動脈および 後下小脳動脈等の血管が顔面神経を直接圧迫す ることで生じるもので, いわゆる neurovascular compression と称されている. 本症例に対して, 一般的には脳神経外科に执いて神経圧迫の減荷 手術，いわゆるJannetta ら1)の手術が行われ ている、脳神経が脳幹へ入り込む部位を root entry zone と称するが，この部位で顔面神経が 血管に圧迫された場合, 顔面神経と第 8 脳神経 の位置関係から類推すると，原因となった血管 が同時に第 8 脳神経を圧迫し影響を及ぼしてい る可能性は充分推測される.
この推測を踏まえて我々は今回, 当院脳神経

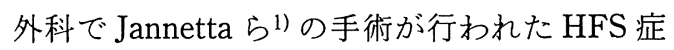
例についてその聴覚・平衡機能検査を検討した. すなわち第 8 脳神経の症状の有無も含め域値上 聴力検査, 各種の平衡機能検査を施行し若干の 知見を得たので報告する.

対 象

当院脳神経外科で手術的治療が行われ, 術前 に当科で聴覚・平衡機能検査がなされた 21 例を 対象とした。

\section{結 果}

(1)自覚症状(表 1)：17例は顔面痙尜の他に自 覚症状はなく，4 例に難聴, 耳鳴, 眩量のうち のいずれかまたは重複の症状があった。内容は 患側のジーという耳鳴が 1 例, 患側の軽度難聴 
が 1 例, 患側のジーといら耳鳴, 軽度難聴およ

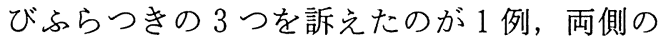
ビーといら耳鳴が 1 例であった.

(2)純音閾值検査（表 2 ）：患側の感音難聴は 3 例で, らち 1 例は自覚症状で難聴, 耳鳴, 眩量 のあった例である．この患側感音難聴併発例の 3 例は次項で詳述する. 両側性感音難聴は 5 例 で，年㱓から考兄て老人性と判断した。さらに 1 例の混合難聴は中耳炎の既往のためと考えた. 健側のみの感音難聴が 2 例もあった.

(3)各種聴覚機能検査 (表 3 ): 患側の感音難聴 例 3 例の結果である.いずれも内耳性と推察さ れた。

(4)耳小骨筋反射(表 4): 14例が反応良好であ った．耳小骨筋反射の経路と HFS の病態を考 えると予想外の結果となった。逆転波形または 反応の悪い 3 例はいずれも患側の顔面神経を経 由する経路の刺激で出現し, 経由しない刺激で は注ぼ正常に反応した. 無反応の 2 例はそれぞ れ両側の高度感音難聴, 過去の中耳炎による鼓

表 1 自覚症状

\begin{tabular}{ccc}
\hline \hline な & し & 17 \\
難 & 聴 & 2 \\
耳 & 鳴 & 3 \\
眩 & 暈 & 1
\end{tabular}

表 2 純音閾值検査

\begin{tabular}{lc}
\hline \hline 正 常 & 10 \\
患側感音難聴 & 3 \\
健側感音難聴 & 2 \\
両側感音難聴 & 5 \\
両側混合難聴 & 1
\end{tabular}

膜の瘢痕化のためと思われた。

(5)聴性脳幹反応 (表 5)：8 例に検査したが患 側の波形出現不良が 2 例あった.

(6)注視眼振, 頭位眼振検査 : 11例に施行した がふらつきのあった 1 例を含め眼振は観察され なかった。

(7)温度眼振検査 : 施行 9 例すべて反応良好で 左右差なかった。

(8)視標追跡検査, 視運動性眼振検査：3 例の みに施行したが異常は認めなかった.

なお上記21例中 16 例に術後にも純音聴力検査 が行われ，1例のみ患側が術前正常より襲にな ったが他は不变だった．術前後とも注視眼振検 査, 頭位眼振検查が行われたのは13例あり術後 3 例に頭位眼振検査で健側向きの眼振が観察さ れた. 2 例が水平性, 1 例が水平回旋混合性眼 振だった. 温度眼振検査は術前後とも施行され たのは 6 例で 3 例が術後患側の反応が低下した.

\section{考察}

患側に感音難聴を合併した 3 例は域値上聴力

表 4 耳小骨筋反射

\begin{tabular}{lr}
\hline \hline 正 常 & 14 \\
逆転波形反応悪い & 3 \\
無反応 & 2
\end{tabular}

表 5 聴性脳幹反応

\begin{tabular}{ll}
\hline \hline 正常 & 5 \\
患側波形出現不良 & 2 \\
判定不能 & 1
\end{tabular}

表 3 各種聴覚機能検査

\begin{tabular}{cccccc}
\hline \hline & 聴力型 & SISI & ABLB & TTDT & 自記オージオグラム \\
\hline (1) R.S. & 高音漸傾型 & 陽 & 疑陽性 & 陰 & 未 \\
(2) M. Y. & 高音漸傾型 & 陽 & 疑陽性 & 未 & Jerger II \\
(3) N. S. & 高音漸傾型 & 陽 & 未 & 陰 & Jerger II
\end{tabular}


検查の結果から内耳性と推察された. neurovascular compression で感音難聴が炭起されれば 通常は後迷路性難聴が予測される.この事とさ らに健側にも感音難聴が 2 例認められた事, 並 びに耳鳴の 3 例が neurovascular compression に特徵的な拍動性でなく金属音類似のものだっ た点も合わせると, 患側に合併した感音難聴は neurovascular compression による感音難聴と は考えにくいと思われた. さらに注視眼振, 頭 位眼振が観察された例はなく，温度眼振検査も すべて反応良好であった．これらからは当科の HFS 例では聴覚平衡障害の合併は考えにくい 結果となった。但し 1 例にふらつきを伴ってい るが, 自発眼振や頭位眼振も認められず温度眼 振検査も異常を認めなかった為原因は不明であ る.

耳小骨筋反射は，19例中14例が反応良好であ った.耳小骨筋反射の経路から考えると反応不 良例が多いと推定していたが，実際には少なか った. HFS 例では顔面神経の障害が軽度で, 顔面神経麻疾症例にみられるような耳小骨筋反 射消失等の重度の障害は惹起しないものと考兄 た。

聴性脳幹反応では 2 例に患側の波形出現不良 がみられた. 大橋ら2)の様に中枢の関与も考え られるが例数が少なく検討できなかった.

顔面神経の neurovascular compression は中 枢性髄䩗から末梢性髄鞘の移行部の root entry zone でおこるとして扣りこれは脳幹近くにあ る. 一方第 8 脳神経の root entry zone は顔面 神経に比べやや末梢部にある. したがって血管 が顔面神経の root entry zone を圧迫しても第 8 脳神経の同部は圧迫されていないため聴覚・ 平衡障害はありえないとされている。深谷ら は57例114耳の自覚症状の問診, 純音聴力検査, 聴性脳幹反応, 温度眼振検査を行い112耳に正 常な所見を得た。そして解剖学的関係や neurovascular compression の発生機序から考 えて HFS と第 8 脳神経の neurovascular compression は独立した疾患であると結論してい
る. 我々の結果も同様で，この論理で説明可能 であった。

一方大橋ら ${ }^{2)}$ は HFS 24例の聴覚・平衡機能 検查から耳鳴, めまいの自覚症状, 自発眼振や 頭位眼振の出現, 温度眼振の低下より, 顔面神 経への血管圧迫だけでなく第 8 脳神経への血管 圧迫も生じている可能性は大きいとしている. また聴性脳幹反応, 眼球運動の異常等より中枢 性, 特に脳幹障害を示唆する所見をえたと報告 している. 当科でも 2 例患側の聴性脳幹反応の 異常が認められたが，その他中枢性を疑わせる 所見はなく HFS に由来するといら確証は得ら れなかった。

他の報告では，丹羽ら ${ }^{4)}$ は HFS 17例中 1 例 に感音難聴があったとし, 横田ら5) は HFS, 三叉神経痛症例の術前術後の純音聴力検査, 聴 性脳幹反応を比較し原因血管の術前の聴覚系へ の影響を推察している。また Møller らの)は acoustic middle ear reflex が HFS 術前の患者 の $41 \%$ に域值上昇または欠如がみられ, 顔面痤 攣を引き起こす血管の圧迫が聴神経にも変化を 引き起こしていると推察している. 大橋ら 2$)$, 横田ら ${ }^{5)}, \quad$ Møller $5^{6)}$ の報告は我々の結果とは 異なっている.

\section{まとめ}

(1)当院でJannetta の手術が行われた一側性 顔面痤攣 21 例の術前の聴覚・平衡機能検査につ き検討した。

(2)一側性顔面痤攣に聴力・平衡障害の合併を 明確に伴った症例はなかった。

\section{文 献}

1) Jannetta PJ, Abbasy M, Maroon JC, et al : Etiology and definitive microsurgical treatment of hemifacial spasm. J Neurosurg $47: 321 \sim 328$, 1977.

2）大橋直樹, 安村佐都紀, 中川 肇, 他 : 顔面痤 攣症例に於ける聴覚 一平衡系の機能異常の検 討一. 耳鼻臨床 補 $36: 145 \sim 152,1989$.

3）深谷 卓, 野村恭也：一側性顔面痤攣症例の聴 覚・前庭機能. 日耳鼻 $92: 2029 \sim 2033,1989$. 
4）丹羽英人, 高安正和 : 顔面痤攣症例に打ける MVD と聴覚. Audiology Japan 27 : 693 694, 1984.

5）横田雅司, 加藤 功, 青柳 優, 他 : Microvascular decompression 術前 - 術後の神経耳科学 的検査所見. Audiology Japan 28:299 300, 1985.

6) Møller MB and Moller AR : Loss of auditory function in microvascular decompression for hemifacial spasm. J Neurosurg $63: 17 \sim 20$, 1985.

(別刷請求先 : 兵 行彦 干480-11 愛知県愛知郡長久手町 大字岩作字雁又 21

愛知医科大学耳鼻咽喉科学教室 